\title{
The employability of ex-offenders: a field experiment in the Swedish labor market
}

\author{
Ali M. Ahmed ${ }^{*}$ and Elisabeth Lång
}

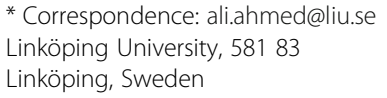

* Correspondence: ali.ahmed@liu.se Linköping, Sweden

\begin{abstract}
This paper presents the findings of a field experiment on hiring discrimination against ex-offenders in the Swedish labor market. Matched pairs of written job applications for fictitious male and female applicants with and without a past conviction of assault were sent to employers for nine different occupations. Results show that discrimination against ex-offenders exists, but the extent of it varies across occupations. The past conviction of assault was associated with 7-18 percentage point lower probability of receiving a positive employer response. Discrimination against ex-offenders was pronounced in female-dominated and highskilled occupations. The magnitude of discrimination against ex-offenders did not vary by applicants' sex.
\end{abstract}

JEL Classification: C93, J71, K42

Keywords: Ex-offenders, Field experiments, Labor market discrimination

\section{Introduction}

Economic measures of success reveal significant inequalities between ex-offenders and non-offenders in the labor market in many countries. Research on ex-offenders' labor market performance suggests that a criminal past has negative consequences on various labor market outcomes, such as employment and earnings (Lott 1990; Waldfogel 1994; Grogger 1995; Needels 1996; Borland and Hunter 2000; Western et al. 2001; Western 2002; Pager 2003; Pager et al. 2009a; Pager et al. 2009b; Holzer et al. 2005; Holzer et al. 2006; Kling 2006; Graffam et al. 2008; Apel and Sweeten 2010; Dominguez Alvarez and Loureiro 2012; Baert and Verhofstadt 2015). Being deprived of labor market opportunities due to a criminal background has serious consequences for ex-offenders and for society as a whole. For ex-offenders, barriers to the labor market can affect their economic well-being and health (Link and Phelan 2001; Major and O'Brien 2005). This is problematic both for the individual and society, since disadvantages in the labor market may encourage or force ex-offenders to bounce back to the criminal world and fail to reintegrate into society post-punishment (Needels, 1996; $\mathrm{Wu}$ and $\mathrm{Wu}, 2012)$. Barriers to the labor market for ex-offenders can, therefore, have significant economic consequences in society in terms of increased crime and criminal victimization along with lost human resources and productivity. Hence, it is important

(c) The Author(s). 2017 Open Access This article is distributed under the terms of the Creative Commons Attribution 4.0 International License (http://creativecommons.org/licenses/by/4.0/), which permits unrestricted use, distribution, and reproduction in any medium, provided you give appropriate credit to the original author(s) and the source, provide a link to the Creative Commons license, and indicate if changes were made. 
both from an individual and societal point of view to get ex-offenders integrated in the labor market and into society.

In the present study, we tested the discrimination hypothesis by applying a correspondence test field experiment in the Swedish labor market. We utilized a field experiment since it has proven to be an efficient and powerful methodology to document evidence of discrimination against different groups of people in various markets (Riach and Rich 2002; Pager 2007; Baert 2017; Bertrand and Duflo, 2017). We developed carefully matched pairs of written applications for fictitious applicants with and without a past conviction of assault. The applications were designed for nine different occupations and consisted of a short e-mail, a narrative application letter, and a CV. Pairs of applications, one from an applicant with a conviction of assault and one from an applicant without a conviction of assault, were sent during a 4-month period in 2016 to employers with available job vacancies posted on the Swedish Public Employment Office website. We used typical Swedish female and male names to signal the applicants' sex. The criminal background of the convicted applicants was revealed by adding a clause in their narrative application letter. In this clause, the ex-offenders revealed that they had been previously convicted of assault and that they were serving a punishment of $90 \mathrm{~h}$ of community service during their free time. Differences in the probability of receiving a positive response from employers between applicants with and without criminal background were interpreted as discrimination.

There are a number of previous studies that have used field experiments to examine whether ex-offenders are discriminated against in the labor market (Schwartz and Skolnick 1962; Buikhuisen and Dijksterhuis 1971; Boshier and Johnson 1974; Pager 2003; Pager et al. 2009a; Pager et al. 2009b; Uggen et al. 2014; Baert and Verhofstadt 2015; Decker et al. 2015; Agan and Starr 2016, 2017). ${ }^{1}$ Table 1 gives an overview of these studies, their designs, and main results. The three earliest studies, Baert and Verhofstadt (2015) and Agan and Starr (2016, 2017), all utilized a correspondence test experiment, i.e., fictitious written applications were sent to employers. ${ }^{2}$ Studies conducted by Uggen et al. (2014) and Pager and associates were all situation test experiments (audit studies) in which real people were recruited, acted as job applicants, and approached employers in person. Decker et al. (2015) used both approaches.

All studies used male job applicants only, and except for Baert and Verhofstadt (2015), all studies focused on low-skilled, entry-level occupations. Criminal background of the ex-offender varied across studies. Furthermore, Baert and Verhofstadt (2015) focused on juvenile delinquency, and the studies of Agan and Starr (2016, 2017), Uggen (2014), and Pager and associates incorporated the role of race in their studies. ${ }^{3}$ Agan and Starr (2016) conducted a comprehensive before-and-after evaluation of the "Banthe-Box" movement (i.e., preventing employers from asking criminal-backgroundrelated questions) in the USA. Table 1 presents their findings for the pre-policy period, given in Agan and Starr (2017). ${ }^{4}$ The findings are quite consistent throughout the previous literature. Except for Boshier and Johnson (1974) and Uggen (2014), all other studies found significant differences in the probability of receiving positive responses from employers between job applicants with and without a criminal background.

Despite the uniformity of the results in previous studies, we make some meaningful contributions to the field. First of all, Table 1 shows that in the three studies conducted by Pager and associates, the information given in the application for the ex-offenders 
Table 1 Prior field experiments on the employability of ex-offenders

\begin{tabular}{|c|c|c|c|c|}
\hline Study, design, country & Crime stimuli & CVs & Jobs & Ratio \\
\hline Schwartz and Skolnick (1962), correspondence, USA & Assault, unstated punishment & 100 & 100 & $2.70^{* *}$ \\
\hline $\begin{array}{l}\text { Buikhuisen and Dijksterhuis (1971), correspondence, } \\
\text { Netherlands }\end{array}$ & $\begin{array}{l}\text { Theft, drunk driving, revoked } \\
\text { driver license }\end{array}$ & 150 & 150 & $1.79^{* * *}$ \\
\hline $\begin{array}{l}\text { Boshier and Johnson (1974), correspondence, } \\
\text { New Zealand }\end{array}$ & $\begin{array}{l}\text { Theft, drunk driving, unstated } \\
\text { punishment }\end{array}$ & 122 & 61 & 1.22 \\
\hline Pager (2003), audit, USA & Drug felony, 18 months of jail & 700 & 350 & $2.26^{* * *}$ \\
\hline $\begin{array}{l}\text { Pager et al. (2009a), } \\
\text { audit, USA }\end{array}$ & Drug felony, 18 months of jail & 340 & 340 & $1.80^{* * *}$ \\
\hline Pager et al. (2009b), audit, USA & Drug felony, 18 months of jail & 500 & 250 & $1.87^{* * *}$ \\
\hline Uggen et al. (2014), audit, USA & $\begin{array}{l}\text { Disorderly conduct, no charge } \\
\text { or conviction }\end{array}$ & 600 & 300 & 1.14 \\
\hline $\begin{array}{l}\text { Baert and Verhofstadt (2015), correspondence, } \\
\text { Belgium }\end{array}$ & $\begin{array}{l}\text { Juvenile delinquency, } 1 \text { year of } \\
\text { open detention }\end{array}$ & 972 & 486 & $1.29^{*}$ \\
\hline Decker et al. (2015), audit, USA & Drug felony, 6 months of jail & 266 & 57 & $1.77^{*}$ \\
\hline Decker et al. (2015), correspondence, USA & Drug felony, 6 months of jail & 3108 & 518 & 1.16 \\
\hline Agan and Starr $(2016,2017)$, correspondence, USA & $\begin{array}{l}\text { Drug or property felony, } \\
\text { unstated punishment }\end{array}$ & 2655 & 1426 & $1.60^{* * *}$ \\
\hline
\end{tabular}

Notes: Ratio is calculated by dividing the positive employer response rate for the non-offenders by the positive employer response rate for the ex-offenders. A simple $Z$ test is used to determine statistically significant differences between nonoffenders and ex-offenders in positive employer response rates. If the number of CVs is larger than the number of jobs for a study, it indicates that more than one application was sent to each employer. Only male job applicants were used in all prior studies. Studies by Pager and associates, Uggen et al. (2014), Decker et al. (2015), and Agan and Starr (2016, 2017) also included an element of race, which is disregarded here. Only overall differences in the probability of receiving a positive response from employers between comparable ex-offenders and non-offenders are considered here. Agan and Starr (2016) conducted a before-and-after analysis of the "Ban-the-Box" movement (i.e., preventing employers from asking criminal background-related questions) in the USA. Only a subset of their data from the pre-policy period, given in Agan and Starr (2017), is considered here ${ }^{* * *} p<0.01,{ }^{* *} p<0.05,{ }^{*} p<0.10$

was that they had been incarcerated for 18 months because of a drug felony. In order to make the ex-offenders and non-offenders as similar as possible in terms of experience and ability, the researchers let their non-offenders graduate 1 year later than exoffenders (accounting for 12 months of difference). For the remaining 6 months, the non-offenders were given 6 months of experience from temporary work just before the job application and the ex-offenders were given 6 months of work experience during their incarceration (accounting for the remaining 6 months). Even though this solution is a crafty one, we argue that it is still likely that employers regarded work experiences gained in and outside jail facilities dissimilar. Moreover, we do not know how nonoffenders graduating 1 year later than ex-offenders influenced employers' decisions. Similarly, in Baert and Verhofstadt (2015), applicants of school leavers with a criminal record declared that they had served time in a 1-year open detention facility for juvenile delinquents during their school years. To make ex-offenders and non-offenders comparable job applicants, it was stated in the ex-offenders' applications that they had continued schooling during their time in the open detention facility. We, again, argue that there is a possibility that employers viewed the education gained by ex-offenders while serving time in an open detention differently than the education gained by nonoffenders. In contrast, Uggen et al. (2014) used disorderly conduct with no charge or conviction to convey a criminal background for the ex-offenders in their experiment and found no statistical difference between ex-offenders and non-offenders in the probability of receiving positive responses from employers. In the earliest experiments and in Agan and Starr $(2016,2017)$, the punishment of the committed crime was 
unmentioned and it is therefore difficult to know what kind of inferences employers may have drawn from the given information. ${ }^{5}$ We therefore avoided using any form of past incarceration of the ex-offenders in our study. For the fictitious ex-offenders in our experiment, we declared that they had been convicted of an assault, that they were under probation, and that they were doing community service as a punishment. Since community service by law has to be done during the free time outside working hours, the applicants with and without a criminal background in our study were equivalent in all other aspects, such as work experience and education.

Second, we included both female and male fictitious applicants in our experiment. Previous studies have not examined whether female ex-offenders are discriminated against in the labor market in similar fashion as male ex-offenders and if there are differences in the treatment of female and male ex-offenders in the labor market. Just as in other countries, men make up the majority of criminals in Sweden's crime statistics. In the case of assault, roughly $80-90 \%$ of all perpetrators are men, depending on how they are counted (Olseryd 2014). However, although small, the number of female criminals in Sweden is undeniably nonzero. Hence, there are no reasons for limiting the study to one sex. It is important both from a policy and theoretical perspective to evaluate the experiences of ex-offenders regardless of their sex.

Third, most previous field experiments on the employability of ex-offenders have been conducted in the US labor market. Equivalent research in the European context is, however, almost absent (with one exception, Baert and Verhofstadt 2015). This is the first field experimental investigation of discrimination against exoffenders in the Swedish society. There is a current political debate in Sweden regarding whether it should be legally forbidden for employers to ask for the criminal record of job applicants. It is from a legal perspective useful to know whether employers act on criminal history information and if legislations against such inquests are necessary.

Fourth, this is the first examination of labor market discrimination against exoffenders in a countrywide field experiment. We argue that it is important to carry out field experiments in cities of various sizes in order to examine whether ex-offenders face more or less difficulties in the labor markets of smaller cities relative to larger cities. Lastly, compared to previous studies, we addressed a larger number of job categories in our field experiment, since discrimination against ex-offenders may vary across different occupations and may be contingent on whether a job task demands low-skilled or high-skilled workers and whether the composition of workers in a job category is female-dominated or male-dominated.

\section{Conceptualization}

From a theoretical point of view, differential treatment of ex-offenders in the labor market can be predicted by both taste-based (Becker, 1957) and statistical (Phelps, 1972; Arrow, 1973) discrimination models. Taste-based discrimination against exoffenders may be the outcome if the employer experience animosity against former criminals. Taste-based discrimination may also result from a company's customers or other employees' preference to not deal with ex-offenders. Statistical discrimination against ex-offenders can occur if employers base their evaluation of an individual applicant on group-level information, such as ex-offenders on average 
being less reliable or ex-offenders on average having lower productivity than nonoffenders. The risk of relapsing into criminality may be an additional reason for statistical discrimination.

Discrimination against ex-offenders may also arise because of ethical motives. Some egalitarian theories consider the punishment of former criminals outside the judicial system in various parts of the society justifiable so that they are punished for the illegal acts they conducted in the past (Fleurbaey 2005). Weak labor market opportunities for jobseekers as a result of a previous criminal record can, from this perspective, be seen as a non-formal, deliberate, or undeliberate punishment by employers. Such views can be criticized for being too strict, since they do not take into account that a person already convicted may be remorseful and that he or she has already formally served his or her sentence (Fleurbaey 2005; Baert and Verhofstadt 2015).

Under the assumption that employers are able to distinguish job applicants with a criminal background from job applicants without a criminal background, the main research hypothesis that we evaluate in this study is that ex-offenders are discriminated against in the labor market. We arrive at this prediction irrespective of different theoretical points of departure. Our current field experiment does not allow us (nor do we attempt) to distinguish between different theoretical perspectives of discrimination against ex-offenders.

On the other hand, we do attempt to examine whether the degree of discrimination against ex-offenders varies with type of occupation. Specifically, we evaluate if the degree of discrimination against applicants with a criminal background depends on whether an occupation requires low-skilled or high-skilled labor, whether an occupation is typically female-dominated or male-dominated, and whether an occupation is located in a big city or a small city.

The reasons for why the degree of the discrimination of ex-offenders may vary with the type of occupation can be depicted as follows. Founded in the contact hypothesis (Allport and Kramer 1946; Allport 1954; Amir 1969), Young and Powell (2015) developed the idea that increased exposure to ex-offenders promotes positive employer relationships with ex-offenders and improves employers' future perceptions of exoffenders. Survey-based studies have shown that people who have had contact with exoffenders hold less negative attitudes towards ex-offenders than those who have had no past interaction with ex-offenders (Hirschfield and Piquero 2010). Other survey-based studies on employers' willingness to hire former criminals have shown that employers' fear of ex-offenders committing new crimes depends on whether employers have had any previous contact with ex-offenders: employers who had experienced previous contact with ex-offenders, frequently or occasionally, had little concern about whether ex-offenders would commit any new crimes (Giguere and Dundes 2002). Hence, if exposure to ex-offenders varies across different types of occupations, the acceptability of ex-offenders may very well vary across occupations as well.

Now, we know that only a small fraction of criminals are women (Olseryd 2014) and that criminals are more likely to belong to the less educated population (Hjalmarsson et al. 2015). We also know that crime rates tend to be higher in big cities than in small cities (Glaeser and Sacerdote 1999). Hence, it is reasonable to believe that the likelihood of employers interacting with ex-offenders is higher in big cities than in small cities, in low-skilled than in high-skilled occupations, and in male-dominated than in female-dominated occupations. As such, we conjecture 
that the acceptability of ex-offenders should be higher, and thus, discrimination against ex-offenders lower, in occupations that involve low-skilled labor, are maledominated, and are located in big cities.

\section{Methodology}

\subsection{Matched pair correspondence test}

Similar to field experimental studies on sex and racial discrimination in the labor market, we utilized a correspondence test experiment in which written job applications for fictitious jobseekers were sent out to employers with available vacancies. ${ }^{6}$ This methodology has lately also been used to document labor market discrimination based on, other than sex and race, a variety of individual characteristics, such as sexual orientation, disability, and attractiveness. ${ }^{7}$ We used a matched pair assignment procedure where we sent two carefully coordinated applications to each employer in our study: one from a fictitious applicant with a criminal record and one from a fictitious applicant with no criminal record. The two matched applications were alternated between the jobseekers with and without a criminal record to avoid unknown and unobservable influences from any remaining differences between the written applications. Each employer in our study received applications from either a pair of two male jobseekers or a pair of two female jobseekers. The sex of each matched pair of applicants was randomly assigned across employers. Hence, each employer had a 50\% chance of receiving a match pair of job applications from two female applicants and a $50 \%$ chance of receiving a match pair of job applications from two male applicants.

\subsection{General characteristics of the fictitious jobseekers}

We used two distinctive female first names, Anna and Sara, two distinctive male first names, Daniel and Johan, and two surnames, Andersson and Eriksson, in order to create two pairs of applicants: one female pair and one male pair of applicants. All first names and surnames were typical Swedish names and among the most common and popular names in Sweden, according to Statistics Sweden. ${ }^{8}$ Using these names, we created two female applicants, Anna Eriksson and Sara Andersson, and two male applicants, Daniel Andersson and Johan Eriksson. Four mobile phone numbers with voicemail and four e-mail accounts were acquired to which employers could address their responses. The fictitious applicants were also given resident addresses located in similar neighborhoods in central Stockholm. ${ }^{9}$

During the execution of our experiment, all of our fictitious applicants were 28 years old (born either August 18, 1987, or July 29, 1987) and had a partner and no children. The applicants had 4 to 9 years of work experience, depending on how much education a specific occupation required. The applicants were interested in recreation and physical activity (to signal that they were healthy) and cultural activities. These interests were carefully matched between the paired applications and randomized over treatment conditions.

\subsection{Job categories}

We targeted occupations with various compositions of men and women, i.e., occupations that are male-dominated and female-dominated. Also, we included both lowskilled and high-skilled occupations. Lastly, we only selected occupations where the job 
availability was good enough to conduct an experiment. Given these prerequisites, we ended up conducting our field experiment on nine broadly defined occupations. We included five female-dominated occupations (accounting clerk, enrolled nurse, preschool teacher, cleaner, and restaurant worker) and four male-dominated occupations (software developer, salesperson, truck driver, and auto mechanic). We roughly classified the selected occupations into male-dominated and female-dominated occupations based on the distribution of men and women across different occupations in Sweden. The share of women among accounting clerks, enrolled nurses, preschool teachers, cleaners, and restaurant workers was $87,93,96,76$, and $68 \%$, respectively, and the share of men among software developers, salespersons, truck drivers, and auto mechanics was 79, 71, 94, and 96\%, respectively, during 2014 (Statistics Sweden 2016). ${ }^{10}$

As mentioned earlier, we also classified our selected occupations into low-skilled and high-skilled jobs. We simply defined low-skilled jobs as occupations that do not require any education at the university level and high-skilled jobs as occupations that do require a university degree. Applying this definition, we had five low-skilled (enrolled nurse, cleaner, truck driver, auto mechanic, and restaurant worker) and four highskilled (accountant clerk, preschool teacher, software developer, and salesperson) occupations in our study.

\subsection{Labeling ex-offenders}

The applications needed to be realistic. We, therefore, followed the recommendations of the Swedish Public Employment Office when creating the cover letters and CVs, consulted experts in relevant occupations, and studied real-life applications and applications used in previous field experiments in the labor market. The applications contained three parts. The first part consisted of a short message in an e-mail, where the applicants stated that they were interested in the vacant position. The second part consisted of a letter, which was enclosed with the e-mail. This letter delivered a narrative account of both formal information such as name, age, education, and work experience and current employment and information about the applicants' personality and interests. The third part of the application was a CV, which provided date of birth, contact information, complete record of education and work experience, and information about language skills, computer skills, and possession of driver license.

The sex of the applicants was signaled through their names given in all three parts of the application. The criminal record of ex-offenders in the treatment condition was revealed in the second part of the application, the narrative application letter. We added a short paragraph in this letter to reveal the ex-offender's criminal record to the employers. We used the following formulation to disclose ex-offenders in our study (English translation):

With good intentions, I wish to express my sincerity and cooperativeness by informing you that I during the last year was convicted of an assault. The assault was an unfortunate incident that took place over a year ago and for me it is a thing of the past. I am also very regretful for this incident. I am serving my sentence through 90 hours of community service at a nonprofit organization, of which I have 35 hours left to perform. The community service is performed on my free time and, therefore, does not affect my other commitments. 
The purpose of the first sentence was to signal good intentions and to give the impression that the applicants did not want to hide anything from their past. The purpose of the second and third sentences was to clearly declare remorsefulness. The second to last sentence informed about the punishment, and the last sentence asserted that the community service was done on the applicant's free time outside ordinary work. This last part was important in order to clarify that the punishment had not interrupted the applicant's work experience and it would not interrupt the applicant's work in the future. Of course, in the matched pair of applications that were sent to employers, the above clause was only included in the ex-offender's application and not in the nonoffender's application. Except for the above clause, all other information was carefully matched between the two applicants in a matched pair and only altered for different targeted occupations.

At this point, it is important to discuss how realistic the content of the above clause is and the reasons for specifically using assault as a crime in our experiment for our fictitious ex-offenders. According to the Swedish National Council for Crime Prevention, assault is one of the most common types of offences in society (Granath 2012). The Swedish Penal Code defines assault as a crime in which an offender inflicts bodily injury, illness, or pain to another person or renders a person powerless or in a similar helpless state (Swedish Code of Statutes 1962:700). The law specifies penalties that vary from fines for minor assault to imprisonment for up to 10 years for severely aggravated assault. An inquiry published by the Swedish Public Prosecution Authority (2007) shows that the most common penalty for assault of intermediate degree (neither minor nor severe) is a suspended sentence in combination with community service or fines. Hence, we chose to declare a history of assault of an intermediate degree for our ex-offenders in order to make our case as realistic and believable as possible both in terms of crime type and in terms of penalty. We wanted the type of crime to be serious enough so that employers would not regard the crime as negligible and we also wanted the type of crime to be not too serious so that employers would not disregard an application from an ex-offender too easily. Further, we wanted the penalty of the crime to be such that the penalty did not require any absence from work and such that the ex-offender did not lose any work experience. Courts can sentence between 40 and $240 \mathrm{~h}$ of community service according to the Swedish Prison and Probation Service. ${ }^{11}$ We chose to use $90 \mathrm{~h}$ of community service, which roughly corresponds to 3 months of imprisonment (Andersson and Wahlin 2003).

We also need to partially address the question, how reasonable is it to disclose the criminal record in a job application? Discrimination is forbidden by law in Sweden. The Discrimination Act is, however, limited to combat unequal treatment on the grounds of sex, transgender identity or expression, ethnicity, religion or other belief, disability, sexual orientation, and age (Swedish Code of Statutes 2008:567). Discriminating on the grounds of having a criminal record is not forbidden by this Act, meaning that the law allows employers to discriminate against jobseekers with a criminal history. For most occupations, ex-offenders are not obliged to reveal their criminal record to their employers. One exception is employers within the child education and childcare sector, who, according to The Education Act, are liable to inspect whether their potential employees have any felony conviction in the past, i.e., 
any convictions concerning sex crimes, murder, homicide, aggravated assault, kidnapping, aggravated robbery, and child pornography offence (Swedish Code of Statutes 2010:800). Nevertheless, there is an increasing trend among employers in all occupations to ask jobseekers for an extract from the criminal records registry (Backman 2012). ${ }^{12}$ This trend has raised serious concerns about job applicants' integrity and treatment in the labor market, and as a consequence, a recent governmental inquiry has resulted in a proposition to legally forbid employers, in sectors other than child education and childcare, to request that job applicants submit an extract from the criminal records registry (Swedish Government Official Reports 2014:48). Hence, if job applicants predict that employers are likely to ask for their crime record, then, we believe that it is reasonable to assume that an honest ex-offender may disclose his or her criminal record for a potential employer in order to show good faith.

\subsection{Application procedure and documentation}

We conducted the field experiment during the period of January 28, 2016, to May 31, 2016. Available job vacancies were found using the job database Platsbanken on the Swedish Public Employment Office website, which is the largest job search channel in Sweden. ${ }^{13}$ We only applied to available vacancies that accepted job applications through e-mail or simple online forms. For practical reasons, we avoided applying to job openings that required us to sign up using complicated online application systems (about $10 \%$ of all available jobs).

For each application sent, we documented the applicant's sex, experimental treatment (ex-offender or not), type of occupation, and version of the matched application letter used. Furthermore, from the job advertisements, we documented the date of application, the city in which the position was advertised, if it was a full-time or part-time position, and if it was a permanent or temporary position. The employers' responses to the job applications were documented as a binary dependent variable. If employers offered the applicants a job interview or an immediate job offer, this was documented as a positive response. Instant job offers were, however, uncommon. Job interviews and job offers were quickly and respectfully declined to minimize the inconvenience for the employers. The complete list and description of variables recorded and analyzed in this study are presented in Table 2 .

\subsection{Study limitations}

At this point, we would like to briefly discuss some limitations of our study and correspondence test experiments in general. For a detailed discussion of limitations regarding labor market field experiments, see Riach and Rich (2002), Pager (2007), Beart (2017), and Bertrand and Duflo (2017). Also, for a discussion regarding ethical issues concerning labor market field experiments on discrimination, see Riach and Rich (2004a, 2004b).

First, it is important to underline that correspondence test experiments only measure discrimination in the first stage of the experiment. Any observation of unequal treatment in the current experiment can, therefore, not be generalized to later stages in the recruitment process. It is even less likely to say anything about earnings disadvantages. Some researchers, however, argue that lower chances of receiving a positive 
Table 2 Description of variables

\begin{tabular}{|c|c|}
\hline Variables & Explanation \\
\hline \multicolumn{2}{|l|}{ Outcome variable $(y)$} \\
\hline Positive response & $\begin{array}{l}1 \text { if an applicant received a promising response (interview invite or job offer) } \\
\text { from an employer, } 0 \text { otherwise }\end{array}$ \\
\hline \multicolumn{2}{|l|}{ Explanatory variables $(x)$} \\
\hline Ex-offender & 1 if the fictitious applicant was an ex-offender, 0 otherwise \\
\hline Female applicant & 1 if the fictitious applicant was a woman, 0 otherwise \\
\hline Job fixed effects & $\begin{array}{l}1 \text { if the job applied belonged to a particular occupation (one dummy for each } \\
\text { occupation), } 0 \text { otherwise }\end{array}$ \\
\hline Female job & 1 if the job belonged to a female dominated occupation, 0 otherwise \\
\hline Female HRM & 1 if the human resource manager was a woman, 0 otherwise \\
\hline High-skill job & 1 if the occupation required a university degree, 0 otherwise \\
\hline Urban & 1 if the job placement was in Göteborg, Malmö, or Stockholm, 0 otherwise \\
\hline \multicolumn{2}{|l|}{ Control variables (c) } \\
\hline Full-time & 1 if the job opening offered a full-time position, 0 otherwise \\
\hline Tenure & 1 if the job opening offered a tenured position, 0 otherwise \\
\hline County fixed effects & $\begin{array}{l}1 \text { if the job was located in a particular county (one dummy for each county), } \\
0 \text { otherwise }\end{array}$ \\
\hline Season fixed effects & $\begin{array}{l}1 \text { if the job was applied to in a specific month (one dummy for each month), } \\
0 \text { otherwise }\end{array}$ \\
\hline Application template & 1 if the first application package out of two matched ones was used, 0 otherwise \\
\hline Application order & 1 if a fictitious applicant (out of two) applied first to an employer, 0 otherwise \\
\hline
\end{tabular}

Notes: There were nine different occupations: accounting clerk, auto mechanic, cleaner, enrolled nurse, preschool teacher, restaurant worker, salesperson, software developer, and truck driver. Female-dominated occupations were accounting clerk, cleaner, enrolled nurse, preschool teacher, and restaurant worker. High-skill occupations were accounting clerk, preschool teacher, salesperson, and software developer. Sweden consists of 21 counties. The experiment was conducted from January to May

response from employers in the initial stage of the recruitment process may still flag us about possible disadvantages in the later stages of the recruitment process and in earnings (Baert et al. 2015; Bertrand and Mullainathan 2004).

Second, we applied to jobs advertised on the Swedish Public Employment Office website. Even though this is the most common channel for job search, it does not represent the entire labor market in Sweden. If ex-offenders have more or less difficulties in finding a job through other channels than the Swedish public Employment Office website, then we probably will under- or overestimate, respectively, the magnitude of discrimination. Hence, caution should be taken in interpreting the magnitude of discrimination and generalizing the results to the entire market.

Third, mentioning a criminal background in the application may convey other signals than just being an ex-offender, for example, belonging to a lower socio-economic group or having problematic social relations with people. We argue that these types of associations and beliefs constitute a source of statistical discrimination. Disentangling various sources of discrimination is, however, out of the scope of this study.

Finally, we would like our readers to keep in mind that the occupational level characteristics by which we estimate heterogeneous treatment effects may very well be correlated with unobservable factors at the same level. Baert et al. (2015), for example, show that labor market discrimination correlates with labor market tightness. Hence, our findings with respect to occupational level characteristics may not be causal. 


\section{Results}

\subsection{Descriptive statistics and main results}

Table 3 tabulates the average response rates for the total sample and for the applicants with and without a criminal background. Table 3 shows that in total, we applied to 1039 jobs, for a total of 2078 job applications sent during the experiment. ${ }^{14}$ For the total sample, job applications led to a positive employer response in $22 \%$ of the cases. Employers' positive response rate varied, however, across different occupations, ranging from $11 \%$ for the occupation cleaner to $36 \%$ for the occupation preschool teacher. Table 3 shows that the positive response rate varied considerably between job applicants with and without a criminal background. In total, non-offenders received a positive response from employers in $28 \%$ of the cases while ex-offenders received a positive response from the employers in $16 \%$ of the cases. This means that nonoffenders received $72 \%$ more positive responses than did ex-offenders. There are noteworthy differences in positive response rates between the ex-offenders and non-offenders in all occupations except in the occupation truck driver. In most occupations, non-offenders received between 50 and $100 \%$ more positive responses than ex-offenders. The largest difference in response rate was in the occupation accounting clerk, where non-offenders received almost five times more positive responses than ex-offenders.

In Table 4, we rearranged the data to show the distribution of employers' responses in order to test for the statistical significance of the observed differences. What is of interest is not the mean differences in positive response rates between non-offenders and ex-offenders but rather to assess whether there is a regularity between the number of employers who only responded to the non-offender and the number of employers who only responded to the ex-offender. Table 4 tabulates the number of employers who did not respond to either of the applicants (Neither), employers who responded positively to both of the applicants (Both), employers who only responded positively to the applicant without any criminal background (Non-offender), and employers who only responded positively to the applicant with a criminal background (Ex-offender). The distribution of responses is presented for the total sample as well as for each occupation. The last column in Table 4 gives the net discrimination, which is simply the

Table 3 Fractions of job applications that led to a positive employer response

\begin{tabular}{lllccc}
\hline Occupation & Number of employers & All & Non-offender & Ex-offender & Ratio \\
\hline Accounting clerk & 74 & 0.16 & 0.26 & 0.05 & 4.75 \\
Auto mechanic & 66 & 0.24 & 0.26 & 0.23 & 1.13 \\
Cleaner & 132 & 0.11 & 0.15 & 0.08 & 2.00 \\
Enrolled nurse & 71 & 0.25 & 0.30 & 0.20 & 1.50 \\
Preschool teacher & 136 & 0.36 & 0.49 & 0.23 & 2.13 \\
Restaurant worker & 301 & 0.20 & 0.25 & 0.16 & 1.57 \\
Salesperson & 69 & 0.27 & 0.33 & 0.20 & 1.64 \\
Software developer & 71 & 0.35 & 0.46 & 0.23 & 2.06 \\
Truck driver & 119 & 0.12 & 0.11 & 0.13 & 0.87 \\
All occupations & 1039 & 0.22 & 0.28 & 0.16 & 1.72 \\
\hline
\end{tabular}

Notes: Ratio is calculated by dividing the fraction of applications that led to a positive employer response for the non-offender by the fraction of applications that led to a positive employer response for the ex-offender 
Table 4 Distribution of employers' responses to the fictitious job applicants

\begin{tabular}{lllllll}
\hline Occupation & Number of employers & Neither & Both & Non-offender & Ex-offender & Net discrimination \\
\hline Accounting clerk & 74 & 53 & 2 & 17 & 2 & $-15^{* * *}$ \\
Auto mechanic & 66 & 46 & 12 & 5 & 3 & -2 \\
Cleaner & 132 & 111 & 9 & 11 & 1 & $-10^{* * *}$ \\
Enrolled nurse & 71 & 43 & 7 & 14 & 7 & -7 \\
Preschool teacher & 136 & 69 & 30 & 36 & 1 & $-35^{* * *}$ \\
Restaurant worker & 301 & 220 & 40 & 34 & 7 & $-27^{* * *}$ \\
Salesperson & 69 & 43 & 11 & 12 & 3 & $-9^{* *}$ \\
Software developer & 71 & 36 & 14 & 19 & 2 & $-17^{* * *}$ \\
Truck driver & 119 & 101 & 10 & 3 & 5 & 2 \\
All occupations & 1039 & 722 & 135 & 151 & 31 & $-120^{* * *}$ \\
\hline
\end{tabular}

Notes: "Neither" and "Both" are the number of cases in which both applicants failed and succeeded, respectively, and "Ex-offender" and "Non-offender" are the number of cases in which only the applicant with and without a criminal history, respectively, succeeded to receive a positive response from an employer. "Net discrimination" is the difference between cases given in columns "Ex-offender" and "Non-offender." The null hypothesis of symmetry between the number of employers who favored the non-offender and the number of employers who favored the ex-offender was evaluated using a two-sided binomial exact test

${ }^{* * *} p<0.01,{ }^{* *} p<0.05$

difference between the number of employers who only responded to the ex-offender and the number of employers who only responded to the non-offender.

Accordingly, we tested the following null hypothesis of regularity:

$$
\frac{n_{N}}{n_{N}+n_{E}}=\frac{1}{2}
$$

where $n_{N}$ represents the number cases where only non-offenders received a positive response and $n_{E}$ represents the number of cases where only ex-offenders received a positive response, as given in Table 4. We evaluated the null hypothesis of equal treatment by calculating an exact two-sided $p$ value based on the binomial probability distribution.

Table 4 shows that we can reject the null hypothesis of equal treatment for the total sample and in six out of nine occupations. Applicants with a criminal background faced unequal treatment in the occupations accounting clerk, cleaner, preschool teacher, restaurant worker, salesperson, and software developer. Hence, discrimination against ex-offenders was not observed in the occupations auto mechanic, enrolled nurse, and truck driver. We can make several important observations in Table 4. First, discrimination against ex-offenders exists in the Swedish labor market. Second, discrimination exists in both male-dominated and femaledominated occupations. Third, discrimination exists in both high-skilled and lowskilled occupations. Fourth, discrimination is not observed in all occupations, confirming the importance of including several types of occupations in these kinds of experiments.

\subsection{Regression analysis}

We proceeded by analyzing the differences between applicants with and without a criminal background as regards the probability of receiving a positive response from 
employers using various specifications of a probit model that takes the following general form:

$$
\operatorname{Pr}\left(y_{j}=1 \mid x_{j}, c_{j}\right)=\Phi\left(x_{j}^{\prime} \beta+c_{j}^{\prime} \gamma\right),
$$

where $j$ is used to index the observations of our sample, $\Phi$ is the cumulative distribution function of the standard normal distribution, $x$ is a vector of explanatory variables, and $c$ is a vector of control variables included in all of our models. The description of variables included in vectors $x$ and $c$ has already been given in Table 2. The various specifications of the above model that will follow vary in what is included in vector $x$ and are estimated separately for male and female applicants. Vector $c$ includes a dummy for full-time position, a dummy for tenure, county dummies, season dummies, an application template dummy, and an order of application dummy. The estimates for vector $c$ are, with a few exceptions, not statistically significant and are, therefore, not reported in the tables. All results remain stable if vector $c$ is omitted from the model. Using a linear probability model instead of a probit model produces similar results. Using a fixed-effects model (at the employer or vacancy level) also generates the same results. The unreported model variations, estimations, and results are available upon request. Since the parameters $\beta$ cannot be interpreted directly, we report the marginal effect of a change in the $k$ th variable $x_{j k}$ on the expected value of the observed variable $y_{j}$ in all tables.

In Table 5, we regress the employer response dummy on the dummy variable for exoffender (model $i$ ) and then on occupation fixed effects and their interactions with the dummy variable for ex-offender (model $i$ ) for male applicants. The results of model $i$ in Table 5 reveal that male applicants with a criminal background had a 10 percentage

Table 5 Positive employer response probabilities for male applicants as a function job categories

\begin{tabular}{llll}
\hline & $\begin{array}{l}\text { Model } i \\
\text { Marginal effect for an } \\
\text { ex-offender }\end{array}$ & $\begin{array}{l}\text { Model ii } \\
\text { Marginal effects for a } \\
\text { non-offender }\end{array}$ & $\begin{array}{l}\Delta \text { in marginal } \\
\text { effects for an } \\
\text { ex-offender }\end{array}$ \\
\hline $\begin{array}{l}\text { Ex-offender } \\
\text { Accounting clerk }\end{array}$ & $-0.102^{* * *}(0.016)$ & Baseline category & $-0.136^{* * *}(0.030)$ \\
Auto mechanic & & $0.036(0.093)$ & $-0.017(0.047)$ \\
Cleaner & & $-0.096^{*}(0.055)$ & $-0.082^{* * *}(0.031)$ \\
Enrolled nurse & $0.024(0.097)$ & $-0.078(0.055)$ \\
Preschool teacher & $0.124(0.097)$ & $-0.126^{* * *}(0.019)$ \\
Restaurant worker & $-0.013(0.066)$ & $-0.073^{* * *}(0.021)$ \\
Salesperson & & $-0.003(0.080)$ & $-0.059(0.042)$ \\
Software developer & & $0.190(0.119)$ & $-0.134^{* * *}(0.024)$ \\
Truck driver & 1098 & $-0.099^{*}(0.051)$ & $0.005(0.040)$ \\
Observations & 0.086 & & 1098 \\
Pseudo $R^{2}$ & & & 0.116
\end{tabular}

Notes: The table presents the marginal changes in the probability of receiving a positive response from an employer estimated using a probit regression model. Corresponding linear probability models and fixed-effects models generate similar results. The dependent variable is a positive response dummy. Also included in each regression are a dummy for fulltime position, a dummy for tenure, county dummies, season dummies, an application template dummy, and a dummy for order of application. Descriptions of all variables are provided in Table 2. Reported standard errors (in parentheses) are corrected for clustering of the observations at the employer level

${ }^{* *} p<0.01,{ }^{*} p<0.10$ 
point lower probability than male applicants without a criminal background of receiving a positive response from employers. Model $i i$ in Table 5 reports the separate effects of being an ex-offender on the probability of receiving a positive response from employers for each occupation by including occupational dummies and their interactions with the dummy variable for ex-offender. Table 5 shows that there was a significant negative effect of being an ex-offender in five out of nine occupations for male applicants. Male applicants with a criminal background had between 7 and 14 percentage point lower probability than male applicants without a criminal background of receiving a positive response from employers in the occupations accounting clerk, cleaner, preschool teacher, restaurant worker, and software developer. Table 5 also shows that there was no statistically significant disadvantage of being an ex-offender in the occupations auto mechanic, enrolled nurse, salesperson, and truck driver.

Table 6 reports the corresponding results for female applicants. The estimates for model iii show that female applicants with a criminal background compared to female applicants without a criminal background had a 13 percentage point lower probability of receiving a positive response from employers. Estimating the separate effects for each occupation in model $i v$ reveals that female applicants with a criminal background had between 9 and 18 percentage point lower probability than female applicants without a criminal background of receiving a positive response in the occupations accounting clerk, cleaner, preschool teacher, restaurant worker, sales person, and software developer. Table 6 shows no statistically significant differences between female applicants with and without a criminal background in the occupations auto mechanic, enrolled nurse, and truck driver.

Since crime rates are higher among men and among low-skilled people and in larger cities, we argued that the acceptability of ex-offenders in the labor market should be

Table 6 Positive employer response probabilities for female applicants as a function job categories

\begin{tabular}{llll}
\hline & $\begin{array}{l}\text { Model iii } \\
\text { Marginal effect for an } \\
\text { ex-offender }\end{array}$ & $\begin{array}{l}\text { Model iv } \\
\text { Marginal effects for a } \\
\text { non-offender }\end{array}$ & $\begin{array}{l}\Delta \text { in marginal } \\
\text { effects for an } \\
\text { ex-offender }\end{array}$ \\
\hline $\begin{array}{l}\text { Ex-offender } \\
\text { Accounting clerk }\end{array}$ & $-0.134^{* * *}(0.019)$ & Baseline category & $-0.183^{* * *}(0.029)$ \\
Auto mechanic & & $0.111(0.131)$ & $-0.036(0.038)$ \\
Cleaner & & $-0.004(0.081)$ & $-0.117^{* * *}(0.034)$ \\
Enrolled nurse & $0.126(0.108)$ & $-0.079(0.056)$ \\
Preschool teacher & $0.396^{* * *}(0.107)$ & $-0.161^{* * *}(0.024)$ \\
Restaurant worker & $0.084(0.078)$ & $-0.093^{* * *}(0.023)$ \\
Salesperson & & $0.239^{*}(0.137)$ & $-0.137^{* * *}(0.036)$ \\
Software developer & & $0.380^{* * *}(0.131)$ & $-0.130^{* * *}(0.038)$ \\
Truck driver & $-0.118^{*}(0.061)$ & $0.057(0.062)$ \\
Observations & & 980 \\
Pseudo R & 980 & & 0.172
\end{tabular}

Notes: The table presents the marginal changes in the probability of receiving a positive response from an employer estimated using a probit regression model. Corresponding linear probability models and fixed-effects models generate similar results. The dependent variable is a positive response dummy. Also included in each regression are a dummy for full-time positions, a dummy for tenure, county dummies, season dummies, an application template dummy, and a dummy for order of application. Descriptions of all variables are provided in Table 2. Reported standard errors (in parentheses) are corrected for clustering of the observations at the employer level ${ }^{* * *} p<0.01,{ }^{*} p<0.10$ 
higher in male-dominated occupations, low-skilled occupations, and in larger cities. Models $v$-viii in Table 7 evaluate these conjectures. Models $v$ and vi report the interaction effects between the dummy variable for being an ex-offender and dummy variables for female-dominated occupation, high-skilled occupation, and job openings located in the three largest cities in Sweden (Urban) for male and female applicants separately. The values reported in Table 7 represent differences in marginal effects between an applicant with and without a criminal background in the probability of receiving a positive response from an employer. The main effects of the interacted variables and the vector consisting of control variables are also included in each regression but are suppressed in the table. In models vii and viii, we then replace the dummy for female-dominated occupation with a dummy indicating whether the human resource manager was female. We ran these as separate regressions, since the information regarding the sex of the human resource manager was not available for all ads, is strongly correlated with the dummy for femaledominated jobs, and is not entirely reliable. ${ }^{15}$

Models $v$ and $v i$ show that both male and female ex-offenders were worse off in female-dominated occupations and in high-skilled occupations, supporting the conjectures that the acceptability of ex-offenders in the labor market should be higher in male-dominated occupations and in low-skilled occupations. We do not, however, find support for the conjecture that ex-offenders would be better off in larger cities. The difference in probability of receiving a positive response from employers between male applicants with and without a criminal background was 7 and 9 percentage points larger in female-dominated versus male-dominated occupations and in high-skilled versus low-skilled occupations, respectively. The difference in the probability of receiving a positive response from employers between female applicants with and without a criminal background was 9 and 12 percentage points larger in female-dominated versus male-dominated occupations and in high-skilled versus low-skilled occupations, respectively.

In models vii and viii, we again find that both male and female ex-offenders faced more difficulties in high-skilled occupations than in low-skilled occupations. The influence of the sex of the human resource manager on the difference in positive response

Table 7 Factors influencing the difference in positive response probabilities between ex-offenders and non-offenders

\begin{tabular}{lllll}
\hline $\begin{array}{l}\text { Interaction } \\
\text { variable }\end{array}$ & $\begin{array}{l}\text { Model } v \\
\text { Male applicants }\end{array}$ & $\begin{array}{l}\text { Model vi } \\
\text { Female applicants }\end{array}$ & $\begin{array}{l}\text { Model vii } \\
\text { Male applicants }\end{array}$ & $\begin{array}{l}\text { Model viii } \\
\text { Female applicants }\end{array}$ \\
\hline Female job & $-0.071^{* *}(0.030)$ & $-0.089^{* *}(0.035)$ & & $-0.085^{* *}(0.038)$ \\
Female HRM & & & $-0.060(0.038)$ & $-0.131^{* * *}(0.036)$ \\
High-skill job & $-0.093^{* * *}(0.027)$ & $-0.119^{* * *}(0.030)$ & $-0.081^{*}(0.040)$ & $-0.006(0.045)$ \\
Urban & $-0.047(0.033)$ & $-0.023(0.036)$ & $-0.054(0.041)$ & 762 \\
Observations & 1096 & 974 & 808 & 0.143 \\
Pseudo $R^{2}$ & 0.100 & 0.126 & 0.085 & \\
\hline
\end{tabular}

Notes: This table reports the interaction effects between the ex-offender dummy and different job characteristics dummies for male and female applicants. The values represent differences in marginal effects between an ex-offender and a non-offender in the probability of receiving a positive response from an employer estimated using a probit regression model. Corresponding linear probability models and fixed-effects models generate similar results. The dependent variable is a positive response dummy. Also included in each regression are the main effects of the interacted variables, a dummy for full-time positions, a dummy for tenure, county dummies, season dummies, an application template dummy, and dummy for order of application. Descriptions of all variables are provided in Table 2. Reported standard errors (in parentheses) are corrected for clustering of the observations at the employer level

${ }^{* * *} p<0.01,{ }^{* *} p<0.05,{ }^{*} p<0.10$ 
probabilities between ex-offenders and non-offenders was statistically significant only among female job applicants. Model viii shows that female ex-offenders faced more difficulties when the human resource manager was a woman.

\subsection{Sex differences}

Comparison of Tables 5 and 6 and the separate models for male and female applicants in Table 7 suggest that the marginal effects of being an ex-offender for female applicants are somewhat larger than for male applicants. We, therefore, lastly evaluated whether there are any sex differences in the way employers treat male and female exoffenders, i.e., whether there is a difference based on sex as regards the size of the discrimination against ex-offenders. Table 8 reports the results of two separate regressions conducted on pooled data. Model $i x$ regresses the employer response dummy on the dummy variable for ex-offender, the dummy variable for the applicant's sex, and the interaction variable between the dummy for ex-offender and the dummy for the applicant's sex (Female ex-offender). We see that for the total sample, an applicant with a criminal background had an 11 percentage point lower probability of receiving a positive response from employers than an applicant without a criminal background. Further, model $i x$ in Table 8 shows that female applicants had a 6 percentage point higher probability of receiving a positive employer response than male applicants in

Table 8 Sex differences in positive employer response probabilities

\begin{tabular}{llllll}
\hline & $\begin{array}{l}\text { Model } i x \\
\text { Criminal past and } \\
\text { sex effects }\end{array}$ & $\begin{array}{l}\text { Model } x \\
\text { Effects for a male } \\
\text { non-offender }\end{array}$ & $\begin{array}{l}\Delta \text { in effects } \\
\text { for a female }\end{array}$ & $\begin{array}{l}\Delta \text { in effects for } \\
\text { an ex-offender }\end{array}$ & $\begin{array}{l}\Delta \text { in effects } \\
\text { for a female } \\
\text { ex-offender }\end{array}$ \\
\hline $\begin{array}{l}\text { Ex-offender } \\
\text { Female applicant }\end{array}$ & $0.109^{* * *}(0.018)$ & & & & \\
Female ex-offender & $-0.013(0.024)$ & & & & \\
Accounting clerk & & Baseline category & $-0.020(0.082)$ & $-0.155^{* * *}(0.037)$ & $-0.042(0.125)$ \\
Auto mechanic & & $0.022(0.095)$ & $0.018(0.102)$ & $-0.021(0.052)$ & $-0.018(0.064)$ \\
Cleaner & & $-0.116^{*}(0.061)$ & $0.142(0.099)$ & $-0.091^{* *}(0.038)$ & $-0.020(0.071)$ \\
Enrolled nurse & & $-0.009(0.093)$ & $0.065(0.103)$ & $-0.082(0.066)$ & $0.012(0.123)$ \\
Preschool teacher & & $0.119(0.098)$ & $0.170^{* *}(0.081)$ & $-0.145^{* * *}(0.021)$ & $-0.003(0.063)$ \\
Restaurant worker & & $-0.015(0.072)$ & $0.032(0.046)$ & $-0.076^{* * *}(0.024)$ & $-0.014(0.039)$ \\
Salesperson & & $-0.026(0.080)$ & $0.203(0.127)$ & $-0.063(0.047)$ & $-0.090(0.060)$ \\
Software developer & & $0.156(0.116)$ & $0.085(0.102)$ & $-0.150^{* * *}(0.027)$ & $0.074(0.115)$ \\
Truck driver & & $-0.110^{*}(0.058)$ & $-0.061(0.069)$ & $0.002(0.041)$ & $0.054(0.054)$ \\
Observations & 2078 & & & & 2078 \\
Pseudo $R^{2}$ & 0.069 & & & & 0.116
\end{tabular}

Notes: Model ix gives the marginal effects of applicants' sex and being an ex-offender as well as the interaction between applicants' sex and being an ex-offender on the probability of receiving a positive response from an employer. Model $x$ gives the main effects of different jobs in the first column (main effects), the change in marginal effects for female applicants in the second column (interaction between female applicant and job dummies), the change in marginal effects for ex-offenders in the third column (interaction between ex-offender and job dummies), and the change in marginal effects for female ex-offenders in the fourth column (interaction between female applicant, ex-offender, and job dummies). The values were estimated using a probit regression model. Corresponding linear probability models and fixed-effects models generate similar results. The dependent variable is a positive response dummy. Also included in each regression are a dummy for full-time positions, a dummy for tenure, county dummies, season dummies, an application template dummy, and a dummy for order of application. Descriptions of all variables are provided in Table 2. Reported standard errors (in parentheses) are corrected for clustering of the observations at the employer level

${ }^{* * *} p<0.01,{ }^{* *} p<0.05,{ }^{*} p<0.10$ 
our experiments. However, the interaction effect between the dummy variables for criminal background and sex is not statistically significant, suggesting that the size of discrimination against ex-offenders did not vary by applicants' sex in our experiment.

In model $x$, we regress the employer response dummy on occupation fixed effects and on their interactions with the dummy variables for criminal background, on applicant's sex, and on the three-way interactions of occupational fixed effects, criminal background, and applicant's sex. The estimates in the second column for model $x$ in Table 8 show that female applicants were significantly better off in the occupation preschool teacher than male applicants. The estimates reported in the third column for model $x$ simply mirrors the combined results of Tables 5 and 6: Ex-offenders are discriminated against in the occupations accounting clerk, cleaner, preschool teacher, restaurant worker, and software developer and have between 7 and 15 percentage point lower probability than non-offenders to receive a positive employer response. The values reported in the fourth column of model $x$ are estimates for the three-way interactions. None of these three-way interaction effects are statistically significant, implying that there were no statistically significant differences in the size of discrimination against ex-offenders between male and female applicants with a criminal background in different occupations in our experiment.

\section{Conclusions}

This paper has documented the results of a field experimental study concerning discrimination against ex-offenders in the labor market. In line with previous field experiments (Schwartz and Skolnick 1962; Buikhuisen and Dijksterhuis 1971; Pager 2003; Pager et al. 2009a; Pager et al. 2009b; Baert and Verhofstadt 2015; Decker et al. 2015; Agan and Starr 2016, 2017), we find strong support for our main research hypothesis: Ex-offenders are discriminated against in the hiring process in the Swedish labor market. The magnitude of discrimination, however, depends on the type of occupation. We found that ex-offenders were discriminated against in the occupations accounting clerk, cleaner, preschool teacher, restaurant worker, sales person, and software developer. However, we did not observe any statistically significant discrimination against ex-offenders in the occupations auto mechanic, enrolled nurse, and truck driver. Hence, we find support for our criticism of previous studies in that it is important to include a variety of occupations in a labor market field experiment. Otherwise, researchers may find themselves either fishing for discrimination or neglecting discrimination, neither of which can provide effective results.

Moreover, we found that discrimination against ex-offenders was most prominent in female-dominated and high-skilled occupations, supporting our conjectures that we derived based on the contact hypothesis. We argued that since criminals are more likely to be men and less educated, the probability of coming into contact with exoffenders would be higher in a male-dominated population and among low-skilled groups. We therefore conjectured that employers in male-dominated and low-skilled occupations would be more familiar and have higher acceptance towards ex-offenders. In fact, our results showed that ex-offenders were not discriminated against in any of the male-dominated low-skilled occupations included in our study (i.e., auto mechanic and truck driver). We also conjectured that discrimination against ex-offenders would be lower in big cities than in small cities. Crime rates are usually higher in big cities, 
which means that the exposure to ex-criminals would be higher in big cities. Based on the contact hypothesis, all of these components together would lead to higher acceptability of ex-offenders in big cities. We did not, however, find any support for this idea. This result might not be entirely surprising, since, while crime rates are higher in big cities than in small cities, jobs might be more likely to be available in areas within big cities that do not suffer from high rates of crime, which would make our comparison between big and small cities irrelevant. Finally, we also show that female ex-offenders face unequal treatment in the hiring process just as male ex-offenders do. Future research should, therefore, continue this line of work with a study focus on both male and female ex-offenders.

It is worth noting that the offence we used to convey ex-criminality in our experiment was assault, resulting in a conviction that did not involve any kind of incarceration. Hence, in comparison with most previous studies, we used a less grave form of misconduct (Pager 2003; Pager et al. 2009a; Pager et al. 2009b; Baert and Verhofstadt 2015). Still, we observed significant differences in the probability of receiving positive employer responses between applicants that were non-offenders and ex-offenders. We could probably expect the difference in employer response rates between ex-offenders and non-offenders to increase with the seriousness of the crime committed by the exoffenders. Our study shows that there is no doubt that ex-offenders in the labor market and in society face obstacles even if the mark of a criminal act is relatively a less serious one.

Yet, why is it a problem that ex-offenders face difficulties in society, such as unequal treatment in the labor market, and why do we need to do research addressing these difficulties? If employers are encouraged to treat job applicants who have a criminal record similar to those with no criminal record, would law-abiding citizens not have a valid complaint that such encouragement would undermine people's commitment to obeying the law? Should employers not treat a clean criminal history as a positive element in the hiring process: a sort of priority for non-offenders, a reward, and encouragement for virtuous behavior and citizenship? The answer to these questions depends on for how long we as a society want former criminals to atone for their earlier misdeeds. If we believe that formal punishments issued by the legal system reflect the societal view and compensate for and remediate the misdeeds conducted by criminals, then further informal punishments in a society, such as unequal treatment in the labor market, are superfluous.

There is, however, a noteworthy problem with the barriers ex-offenders face in the labor market, regardless of whether one thinks unequal treatment of ex-offenders, post-punishment, is justifiable or not. Although the relationship between labor market participation and criminal activity is complex, research shows that having a job plays a crucial part in preventing recidivism (Visher et al. 2005). Employment incentivizes exoffenders to respect the law and induce a righteous lifestyle and thereby minimizes the likelihood of relapsing into criminal activity (Rakis 2005). Employment also improves the psychological well-being and social relationships and network of ex-offenders, encouraging them to stay on the lawful path in life (Liker 1982; Graffam et al. 2004). On the contrary, unemployment is connected with unlawful behavior and is a strong risk factor for criminal recidivism (Petersilia 2001; McDonough and Burell 2008). Hence, discrimination against ex-offenders is not just a matter of increasing employment 
opportunities for ex-offenders, but it is also a matter of minimizing the risk and societal cost of ex-offenders recidivating into crimes. Allowing ex-offenders to gain steady employment and helping them to successfully reintegrate into society bring improvements in public safety, stimulation of the economy through a larger workforce, increased number of taxpayers, and reduction of crime and punishment costs. All of the above should be in the interests of the whole society.

The field experimental research on labor market discrimination against ex-offenders is still in an early stage. Many questions remain to be answered. Yet, we can with confidence draw at least one overall conclusion based on the existing literature: criminal background does affect employability and ex-offenders are discriminated against in the labor market. Future research should assemble evidence that make us more confident about the extent of discrimination against ex-offenders and the ways discrimination against ex-offenders manifests itself. We end this paper by making a few suggestions for future work.

First, evidence for the European context is limited, as most previous experiments have been conducted in the USA. Replication studies in the European labor markets would improve our understanding of how discrimination against ex-offenders varies across different institutional contexts and labor markets. Second, future studies should evaluate how criminal background interacts with other individual traits, especially those that are known to have a negative impact on people's employability. We know, for example, that immigrants are discriminated against in the labor market in most European countries (see, e.g., Baert et al. 2017; Baert et al. 2015; Baert and Vujić 2016; Carlsson and Rooth 2007; Midtbøen 2016). Do immigrants with a criminal background then face a double penalty in the hiring situation? A number of studies in the USA, for example, have shown that black applicants with a criminal background face such penalties (Pager 2003; Pager et al. 2009a; Pager et al. 2009b). Third, should we ban employers from asking job applicants for a criminal record? What consequences would such policy then have in the labor market? In the USA, Agan and Starr (2016) found that the "Ban-theBox" policy eliminated discrimination against ex-offender, but it also dramatically increased statistical discrimination against black people. Can we expect similar consequences of such policies in the European context for immigrants? Fourth, how does discrimination against ex-offenders vary with the type of crime? For example, how would economic crimes influence a person's employability? Fifth, future research should evaluate the validity of the results found in this study. Is discrimination against female ex-offender replicable in other countries? How does discrimination against exoffenders vary across different occupations in other countries? Finally, future studies should try to identify and disentangle underlying mechanisms of discrimination against ex-offenders. All these extensions and variations of labor market experiments will enhance our understanding and improve our knowledge of how criminal background affects a person's employability.

\section{Endnotes}

${ }^{1}$ Here, we only discuss studies that have specifically tested for discrimination against ex-offenders using field experiments. For other studies on the overall labor market performance of ex-offenders (some of which were aforementioned), see, e.g., the excellent review by Holzer (2009). 
${ }^{2}$ Agan and Starr $(2016,2017)$ actually focused on employers offering jobs with online application forms. We categorize this as a correspondence test experiment.

${ }^{3}$ Not surprisingly, being black and having a criminal background constituted a double penalty in the US labor market. In fact, a white applicant with a criminal background actually received more positive responses than a black applicant with a "clean" record (Pager 2003).

${ }^{4}$ Agan and Starr (2016) showed that the "Ban-the-Box" policy eliminates hiring discrimination against ex-offenders. The policy, however, encourages statistical discrimination on the basis of race and dramatically increases the racial gap in employability.

${ }^{5}$ Since Agan and Starr $(2016,2017)$ applied to jobs with online application forms only, they did not signal criminal background through an application letter or a CV as in the other studies. Instead, criminal background was declared when there was a "box" for it, i.e., when the employer asked for it in the online application.

${ }^{6}$ For some recent field experimental contributions on sex and racial discrimination in the labor market, see Baert (2015), Baert et al. (2017), Baert et al. (2015), Baert et al. (2016a), Baert and Vujić (2016), Darolia et al. (2016), Gaddis (2015), Lee and Khalid (2016), Midtbøen (2016), Nunley et al. (2015), and Zschirnt and Ruedin (2016).

${ }^{7}$ For some recent field experimental studies on labor market discrimination based on other traits than sex and race, see Ahmed et al. (2017), Ameri et al. (2015), Baert (2016), Baert et al. (2016a, 2016b, 2016c), Baert and Omey (2015), Drydakis (2015), Eriksson and Rooth (2014), Hipes et al. (2016), Maurer-Fazio and Lei (2015), Mishel (2016), Patacchini et al. (2015), Ruffle and Shtudiner (2015), Weichselbaumer (2015), and Weichselbaumer (2016).

${ }^{8}$ According to Statistics Sweden, Anna was the first and Sara the seventh most common forenames among women; Johan and Daniel were the fourth and eleventh most common forenames for men, respectively; and Andersson was the first and Eriksson the fifth most common surnames in Sweden, as of December 31, 2015 (http://www.scb.se/be0001).

${ }^{9} \mathrm{E}$-mail addresses were created at one of the largest e-mail providers on the Internet, and prepay mobile telephone numbers with voicemail were obtained from two wellknown mobile network operators in Sweden. The resident addresses were, however, not genuine, since previous field experiments in the Swedish labor market have shown that employers never respond to applications through ordinary post (see, e.g., Ahmed et al. 2012, 2013).

${ }^{10}$ The distribution in terms of sex in the most common occupations held by men and women can also be found online at Statistics Sweden (http://www.scb.se/am0208).

${ }^{11}$ Information retrieved from the website of the Swedish Prison and Probation Service, current as of 20 September, 2016 (see https://www.kriminalvarden.se/fangelse-frivardoch-hakte/frivard/samhallstjanst/).

${ }^{12}$ The criminal records registry includes information about all individuals who have been imposed sanctions for committing a crime (Swedish Code of Statutes 1998:620). In most cases, the crime record is available for a period of 10 years.

${ }^{13}$ About $30-40 \%$ of all available jobs in Sweden are posted on the Swedish Public Employment Office website (Siksjö, 2015). The website is available at http://www.arbetsformedlingen.se/.

${ }^{14} \mathrm{We}$ actually applied to 1046 job openings. However, information for seven vacancies (i.e., 14 observations) was either incomplete (due to missing information in the job 
advertisement for one or more variables of interest, employer email malfunction after the first application, or indecipherable voice messages) or biased (due to human error of the research assistant during the data collection). These observations were, therefore, excluded from the analysis.

${ }^{15}$ The dummy variable for female human resources manager is not entirely reliable in the sense that we actually do not know how much power and influence this person had in the decision-making process of selecting or rejecting job applicants.

\section{Acknowledgements}

We are much obliged to Mark Granberg for his excellent research assistance. We express gratitude to Andreas Kotsadam, Pernilla Ivehammar, Roger Bandick, the editor, and a reviewer for the useful suggestions. We are also grateful to friends and colleagues for the valuable discussions.

Responsible editor: Denis Fougère

\section{Competing interests}

The IZA Journal of Labor Policy is committed to the IZA Guiding Principles of Research Integrity. The authors declare that they have observed these principles.

\section{Publisher's Note}

Springer Nature remains neutral with regard to jurisdictional claims in published maps and institutional affiliations.

Received: 24 April 2017 Accepted: 12 May 2017

Published online: 29 June 2017

\section{References}

Agan AY, Starr SB (2016) Ban the box, criminal records, and statistical discrimination: a field experiment. Law and Economics Research Paper Series 16-012, University of Michigan, Ann Arbor, Michigan

Agan AY, Starr SB (2017) The effect of criminal records on access to employment. Am Econ Rev 107:560-564

Ahmed AM, Andersson L, Hammarstedt M (2012) Does age matter for employability? A field experiment on ageism in the Swedish labour market. Appl Econ Lett 19:403-406

Ahmed AM, Andersson L, Hammarstedt M (2013) Are gay men and lesbians discriminated against in the hiring process? South Econ J 79:565-585

Ahmed AM, Granberg M, Lång E (2017). Does having one's own place to live make someone more employable? Appl Econ Lett. http://dx.doi.org/10.1080/13504851.2016.1276263

Allport GW (1954) The nature of prejudice. Addison-Wesley, Cambridge, MA

Allport GW, Kramer BM (1946) Some roots of prejudice. J Psychol 22:9-39

Ameri M, Schur L, Meera A (2015) The disability employment puzzle: a field experiment on employer hiring behavior. NBER Working Paper 21560, National Bureau of Economic Research, Cambridge, MA

Amir Y (1969) Contact hypothesis in ethnic relations. Psychol Bull 71:319-342

Andersson K, Wahlin L (2003) Samhällstjänst - i samhällets tjänst? Brottsförebyggande rådet, Stockholm

Apel R, Sweeten G (2010) The impact of incarceration on employment during the transition to adulthood. Soc Probl 57:448-479

Arrow KJ (1973) The theory of discrimination. In: Ashenfelter O, Rees A (eds) Discrimination in labor markets. Princeton University Press, Princeton, pp 3-33

Backman C (2012) Criminal records in Sweden: regulation of access to criminal records and the use of criminal background checks by employers. Göteborg Studies in Sociology, Göteborg

Baert S (2015) Field experimental evidence on gender discrimination in hiring: biased as Heckman and Siegelman predicted? Economics-Open Access Open-Assess E J 9:1-11

Baert S (2016) Wage subsidies and hiring chances for the disabled: some causal evidence. Eur J Health Econ 17:71-86

Baert S (2017) Hiring discrimination: an overview of (almost) all correspondence experiments since 2005. IZA Discussion Paper 10738, IZA Institute of Labor Economics, Bonn

Baert S, Omey E (2015) Hiring discrimination against pro-union applicants: the role of union density and firm size. Economist 163:263-280

Baert S, Verhofstadt E (2015) Labour market discrimination against former juvenile delinquents: evidence from a field experiment. Appl Econ 47:1061-1072

Baert S, Vujić S (2016) Immigrant volunteering: a way out of labour market discrimination? Econ Lett 146:95-98

Baert S, Cockx B, Gheyle N, Vandamme C (2015) Is there less discrimination in occupations where recruitment is difficult? ILR Rev 68:467-500

Baert S, De Pauw AS, Deschacht N (2016a) Do employer preferences contribute to sticky floors? ILR Rev 69:714-736

Baert S, De Visschere S, Schoors K, Vandenberghe D, Omey E (2016b) First depressed, then discriminated against? Soc Sci Med 170:247-254

Baert S, Norga J, Thuy Y, Van Hecke M (2016c) Getting grey hairs in the labour market. A realistic experiment on age discrimination. J Econ Psychol 57:86-101

Baert S, Albanese A, du Gardein S, Ovaere J, Stappers J (2017) Does work experience mitigate discrimination? Econ Lett 155:35-38

Becker GS (1957) The economics of discrimination. University of Chicago Press, Chicago 
Bertrand M, Duflo E (2017). Field experiments on discrimination. In: Banerjee A, Duflo E (eds) Handbook of Field Experiment, Volume 1, North Holland, Amsterdam, p 309-393

Bertrand M, Mullainathan S (2004) Are Emily and Greg more employable than Lakisha and Jamal? A field experiment on labor market discrimination. Am Econ Rev 94:991-1013

Borland J, Hunter B (2000) Does crime affect employment status? The case of Indigenous Australians. Economica 67:123-144

Boshier R, Johnson D (1974) Does conviction affect employment opportunities? Br J Criminol 14:264-268

Buikhuisen W, Dijksterhuis FP (1971) Delinquency and stigmatisation. Br J Criminol 11:185-187

Carlsson M, Rooth DO (2007) Evidence of ethnic discrimination in the Swedish labor market using experimental data. Labour Econ 14:716-729

Darolia R, Koedel C, Martorell P, Wilson K, Perez-Arce F (2016) Race and gender effects on employer interest in job applicants: new evidence from a resume field experiment. Appl Econ Lett 23:853-856

Decker SH, Ortiz N, Spohn C, Hedberg E (2015) Criminal stigma, race, and ethnicity: the consequences of imprisonment for employment. J Crim Just 43:108-121

Dominguez Alvarez R, Loureiro ML (2012) Stigma, ex-convicts and labour markets. Ger Econ Rev 13:470-486

Drydakis N (2015) Sexual orientation discrimination in the UK's labor market: a field experiment. Human Relat 68:1769-1796

Eriksson S, Rooth DO (2014) Do employers use unemployment as a sorting criterion when hiring? Evidence from a field experiment. Am Econ Rev 104:1014-1039

Fleurbaey M (2005) Freedom with forgiveness. Polit Philos Econ 4:29-67

Gaddis SM (2015) Discrimination in the credential society: an audit study of race and college selectivity in the labor market. Soc Forces 93:1451-1479

Giguere R, Dundes L (2002) Help wanted: a survey of employer concerns about hiring ex-convicts. Crim Justice Policy Rev 13:396-408

Glaeser EL, Sacerdote B (1999) Why is there more crime in cities? J Polit Econ 107:S225-S258

Graffam J, Shinkfield A, Lavelle B, McPherson W (2004) Variables affecting successful reintegration as perceived by offenders and professionals. J Offender Rehabil 40:147-171

Graffam J, Shinkfield AJ, Hardcastle L (2008) The perceived employability of ex-prisoners and offenders. Int J Offender Ther Comp Criminol 52:673-685

Granath S (2012) Misshandel. In: Hagstedt J (ed) Brottsutvecklingen i Sverige 2008-2011. Norstedts Juridik AB, Stockholm, pp 67-91

Grogger J (1995) The effect of arrests on the employment and earnings of young men. Q J Econ 110:51-71

Hipes C, Lucas J, Phelan JC, White RC (2016) The stigma of mental illness in the labor market. Soc Sci Res 56:16-25

Hirschfield PJ, Piquero AR (2010) Normalization and legitimation: modeling stigmatizing attitudes toward ex-offenders. Criminology 48:27-55

Hjalmarsson R, Holmlund H, Lindquist MJ (2015) The effect of education on criminal convictions and incarceration: causal evidence from micro-data. Econ J 125:1290-1326

Holzer HJ (2009) Collateral costs: the effects of incarceration on employment and earnings among young men. In: Raphael S, Stoll M (eds) Do prisons make us safer? The benefits and costs of the prison boom. Russell Sage, New York, pp 239-268

Holzer HJ, Offner P, Sorensen E (2005) Declining employment among young black less-educated men: the role of incarceration and child support. J Policy Anal Manage 24:329-350

Holzer HJ, Raphael S, Stoll MA (2006) Perceived criminality, criminal background checks, and the racial hiring practices of employers. J Law Econ 49:451-480

Kling JR (2006) Incarceration length, employment, and earnings. Am Econ Rev 96:863-876

Lee HA, Khalid MA (2016) Discrimination of high degrees: race and graduate hiring in Malaysia. J Asia Pac Econ 21:53-76

Liker JK (1982) Wage and status effects of employment on affective well-being among ex-felons. Am Sociol Rev 47:264-283

Link BG, Phelan JC (2001) Conceptualizing stigma. Annu Rev Sociol 27:363-385

Lott JR (1990) The effect of conviction on the legitimate income of criminals. Econ Lett 34:381-385

Major B, O'Brien LT (2005) The social psychology of stigma. Annu Rev Sociol 56:393-421

Maurer-Fazio M, Lei $L$ (2015) As rare as panda. How facial attractiveness, gender, and occupation affect interview callbacks at Chinese firms. Int J Manpow 36:68-85

McDonough J, Burell WD (2008) Offender workforce development: a new (and better?) approach to an old challenge. Fed Probat 72:71-76

Midtbøen AH (2016) Discrimination of the second generation: evidence from a field experiment in Norway. J Int Migr Integr 17:253-272

Mishel E (2016) Discrimination against queer women in the U.S. workforce: a résumé audit study. Socius 2:1-13

Needels KE (1996) Go directly to jail and do not collect? A long-term study of recidivism, employment, and earnings patterns among prison releases. J Res Crime Delinq 33:471-496

Nunley JM, Pugh A, Romero N, Seals RA (2015) Racial discrimination in the labor market for recent college graduates: evidence from a field experiment. BE J Econ Anal Policy 15:1093-1125

Olseryd J (2014) Gärningspersoners kön och ålder vid misshandel, hot, rån och sexualbrott. Brottsförebyggande rådet, Stockholm

Pager D (2003) The mark of a criminal record. Am J Sociol 108:937-975

Pager D (2007) The use of field experiments for studies of employment discrimination: contributions, critiques, and directions for the future. Ann Am Acad Polit Soc Sci 609:104-133

Pager D, Western B, Bonikowski B (2009a) Discrimination in a low-wage labor market a field experiment. Am Sociol Rev 74:777-799

Pager D, Western B, Sugie N (2009b) Sequencing disadvantage: barriers to employment facing young black and white men with criminal records. Ann Am Acad Polit Soc Sci 623:195-213

Patacchini E, Ragusa G, Zenou Y (2015) Unexplored dimensions of discrimination in Europe: homosexuality and physical appearance. J Popul Econ 28:1045-1073

Petersilia J (2001) When prisoners return to the community: political, economic, and social consequences. Fed Probat 65:3-8

Phelps ES (1972) The statistical theory of racism and sexism. Am Econ Rev 62:659-661 
Rakis J (2005) Improving the employment rates of ex-prisoners under parole. Fed Probat 69:7-12

Riach PA, Rich J (2002) Field experiments of discrimination in the market place. Econ J 112:F480-F518

Riach PA, Rich J (2004a) Deceptive field experiments of discrimination: are they ethical? Kyklos 57:457-470

Riach PA, Rich J (2004b) Fishing for discrimination. Rev Soc Econ 62:465-486

Ruffle B, Shtudiner Z (2015) Are good-looking people more employable? Manag Sci 61:1760-1776

Schwartz RD, Skolnick JH (1962) Two studies of legal stigma. Soc Probl 10:133-142

Siksjö D (2015) Hitta de dolda jobben. Platsjournalen 43:2-3

Statistics Sweden (2016) På tal om kvinnor och män 2016. SCB-Tryck, Örebro

Swedish Code of Statutes (1962:700) The Swedish Penal Code. Retrieved September 19, 2016: http://www.riksdagen.se/ sv/dokument-lagar/dokument/svensk-forfattningssamling/brottsbalk-1962700_sfs-1962-700\#K3

Swedish Code of Statutes (1998:620) The Criminal Records Act. Retrieved September 19, 2016: http://www.riksdagen.se/ sv/dokument-lagar/dokument/svensk-forfattningssamling/lag-1998620-om-belastningsregister_sfs-1998-620

Swedish Code of Statutes (2008:567) The Discrimination Act. Retrieved September 19, 2016: http://www.riksdagen.se/ sv/dokument-lagar/dokument/svensk-forfattningssamling/diskrimineringslag-2008567_sfs-2008-567

Swedish Code of Statutes (2010:800) The Education Act. Retrieved September 19, 2016: http://www.riksdagen.se/sv/ dokument-lagar/dokument/svensk-forfattningssamling/skollag-2010800_sfs-2010-800

Swedish Government Official Reports (2014:48) Registerutdrag i arbetslivet. Elanders Sverige AB, Stockholm

Swedish Public Prosecution Authority (2007) Domstolarnas påföljdspraxis vid vissa våldsbrott. Edita AB, Stockholm

Uggen C, Vuolo M, Lageson S, Ruhland E, Whitham HK (2014) The edge of stigma: an experimental audit of the effects of low-level criminal records on employment. Crimonology 52:627-654

Visher CA, Winterfield L, Coggeshall MB (2005) Ex-offender employment programs and recidivism: a meta-analysis. J Exp Criminol 1:295-316

Waldfogel J (1994) The effect of criminal conviction on income and the trust "reposed in the workmen". J Hum Resour 29:62-81

Weichselbaumer D (2015) Testing for discrimination against lesbians of different marital status: a field experiment. Ind Relat 54:131-161

Weichselbaumer D (2016) Discrimination against migrant job applicants in Austria: an experimental study. Ger Econ Rev 18:237-265

Western B (2002) The impact of incarceration on wage mobility and inequality. Am Sociol Rev 67:526-546 Western B, Kling JR, Weiman DF (2001) The labor market consequences of incarceration. Crime Delinquency 47:410-427

Wu D, Wu Z (2012) Crime, inequality and unemployment in England and Wales. Appl Econ 44:3765-3775

Young NC, Powell GN (2015) Hiring ex-offenders: a theoretical model. Hum Resour Manag Rev 25:298-312

Zschirnt E, Ruedin D (2016) Ethnic discrimination in hiring decisions: a meta-analysis of correspondence tests 1990-2015.

J Ethn Migr Stud 42:1115-1134

\section{Submit your manuscript to a SpringerOpen ${ }^{\circ}$ journal and benefit from:}

- Convenient online submission

- Rigorous peer review

Open access: articles freely available online

High visibility within the field

- Retaining the copyright to your article

Submit your next manuscript at $>$ springeropen.com 